\title{
IMPACT OF MUNICIPAL LANDFILL SITE ON WATER QUALITY IN THE WŁOSANKA STREAM
}

\author{
Włodzimierz Kanownik ${ }^{1}$, Agnieszka Policht-Latawiec ${ }^{1}$
}

1 University of Agriculture in Krakow, Al. Mickiewicza 24-28, 30-059 Krakow, Poland, e-mail: rmkanown@cyf-kr. edu.pl; a.policht@ur.krakow.pl

Received: 2016.05 .29

Accepted: 2016.07.30

Published: 2016.09.20

\begin{abstract}
Hydrochemical research conducted in the years 2007-2010 comprised monitoring of the Włosanka stream waters and leachate waters from the municipal landfill in Kulerzów in the Malopolskie province. 16 leachate samples were collected from the container taking into consideration the vertical stratification of the quality and samples of water from the Włosanka stream in measurement points situated before and after the landfill. Concentrations of metals: calcium, magnesium, sodium, potassium, iron, manganese and heavy metals: chromium, zinc, copper, cadmium, nickel and lead were determined in the leachates and the stream water. Analysis of the studied metals in the leachates revealed that only potassium concentration exceeded the highest admissible value which is the condition of introducing sewage to water bodies or to soil. Water along the investigated reach of the Włosanka stream, both above and below the municipal landfill was of quality class 1 . The landfill had no significant effect on the studied metal concentrations in the stream water - no statistically significant differences were registered between the concentrations of the studied metals (including heavy metals) either in the point above or below the landfill. However, statistical tests comparing values of metal concentrations in the landfill leachates with the stream water revealed that the concentrations of 7 out of 12 tested metals were significantly higher in the leachates. Therefore, the landfill site monitoring should be continued, leachate waters should be collected in the container and supplied to the sewage treatment plant to prevent any threat to human life and health, or to the environment.
\end{abstract}

Keywords: water quality, landfill leachate water, heavy metal indices, the Włosanka stream

\section{INTRODUCTION}

A considerable percent of municipal wastes is still stored on landfills [Szyłak-Szydłowski 2011], usually located in natural land depressions [Dmochowska and Dmochowski 2011, Wiater 2011, Piniarski and Macias 2015]. Wrong localization of landfills and their improper exploitation cause that the natural environment, particularly the ground [Longe and Balogun 2010, Grzyb et al. 2015] and surface waters are threatened with pollution [Motyka et al. 2005, Rzepa et al. 2006, Janeczko-Mazur and Nowosielski 2009]. Precipitation waters which permeate through the landfill layer cause leaching of various pollutants and formation of leachates with various properties [Williams 2002, Öman and Junestedt 2008, SzymańskaPulikowska 2010, Długosz 2012, Vergara and Tchobanoglous 2012]. It is caused by the kind of deposited wastes, the landfill age, degradation phase, the degree of waste compaction and the process of the site exploitation [Słomczyńska and Słomczyński 2004]. The leachates in the form of suspended water may be present at various depths of the deposited wastes but also may accumulate on the landfill bottom and permeate through the aeration level into the aquifer [Ogundiran and Afolabi 2008]. The spatial range of hazard to the ground and surface waters posed 
by the leachates from municipal landfill site is strictly connected with the conditions of liquid phase permeating [Wiercik and SzymańskaPulikowska 2010], including the direction of water flow in the ground, the kind and number of leachates, which is particularly important in case of landfills with incomplete structure. Leachate management aims to reduce their number by reclamation of waste deposit and proper exploitation of the landfill [Czop and Pieniążek 2010]. A proper intake and draining of rainwater from the landfill by means of a drainage system positively affects protection of the ground and surface waters [Przydatek 2012]. The process of pollutant leaching from the landfill may last for several dozen or even several hundred years [Srivastava and Ramanathan 2008]. Leachate waters from landfill sites [Koc-Jurczyk and Różak 2011], treated sewage [Kanownik and Rajda 2011, Kowalik et al. 2015] and area pollution from built up terrains [Policht-Latawiec and Kanownik 2015] and agricultural areas [Bogdał et al. 2012, Kowalik et al. 2014] pose a serious hazard to the aquatic environment. Therefore, a constant monitoring of leachate waters is important, at least within the range stated by the Regulation of the Minister of the Environment on the range, period, method and conditions of landfill sites monitoring [Rozporządzenie MŚ 2013a, Mizerna and Bożym 2015].

The aim of the paper is an attempt at determining the impact of leachate waters from municipal landfill site on the surface water quality. The investigations were conducted on the municipal landfill site, closed in 2005, situated in Kulerzów village in Mogilany district, in the immediate vicinity of the Włosanka stream. The paper presents an analysis of 12 water and leachate pollution indices, including heavy metal contents, which are substances particularly harmful for the aquatic environment and terrestrial ecosystems directly dependent on the aquatic environment. Values of concentrations were compared with the normative values and water quality in the stream was assessed above and below the landfill site.

\section{SCOPE AND METHODS OF RESEARCH}

Hydrochemical analyses were conducted in the years 2007-2010. They comprised monitoring of surface water and leachate water from the municipal landfill site in Kulerzów in the Malopolskie province (Figure 1). Each year were taken 4 leachate samples (once pre quarter) in compliance with PN-ISO 5667-10:1997 norm taking into account the vertical stratification of the leachate quality and water samples from the Włosanka stream for laboratory analyses [PN-ISO 5667-10: 1997, PN-ISO 5667-6: 2003, PN-EN ISO 56671: 2008, PN-EN ISO 5667-3: 2013]. Leachates from the landfill site (point 1) were collected by bathometer from a water container, water from the stream by means of a landing net at $\mathrm{km} 3+100$ and $3+500$, respectively above (point 2 ) and below (point 3 ) the landfill site.

The following assessments were made using reference methods in the leachate and stream water [Rozporządzenie MŚ 2013b] concentrations of metals: calcium $\left(\mathrm{Ca}^{2+}\right)$, magnesium $\left(\mathrm{Mg}^{2+}\right)$, sodium $\left(\mathrm{Na}^{+}\right)$, potassium $\left(\mathrm{K}^{+}\right)$, iron $\mathrm{Fe}^{2+}$ and $\mathrm{Fe}^{3+}(\mathrm{Fe})$, manganese $\left(\mathrm{Mn}^{2+}\right)$ and heavy metals: chromium $(\mathrm{Cr})$, zinc $(\mathrm{Zn})$, copper $(\mathrm{Cu})$, cadmium $(\mathrm{Cd})$, nickel $(\mathrm{Ni})$ and lead $(\mathrm{Pb})$ using atomic absorption spectrometry on Unicam Solaar 969 spectrometer. Results obtained for the waters leaching from the landfill site were compared with the values stated in the Regulation of the Minister of the Environment of 18 November 2014 on the conditions which must be fulfilled when introducing sewage to waters or soil [Rozporządzenie MŚ 2014b]. Water quality in the Włosanka river was determined in compliance with Regulation of the Minister of the Environment of 22 October 2014 on the method of classification of groundwater body condition [Rozporządzenie MŚ 2014a].

The following statistical parameters were determined for the analysed metals: minimum and maximum value, arithmetic mean, median, standard deviation and coefficient of variance. Collected results were used for the statistical analysis and drawing conclusions aimed at an assessment of the landfill site impact on surface waters quality. In order to estimate the significance of differences of the investigated stream water indices concentrations above and below the municipal landfill site, to compare the indices in the leachates with the stream water above and below the landfill, and after checking the normality of distribution by means of Shapiro-Wilk test, t-Student test was applied for the normal distribution and the Mann-Whitney non-parametric U-test, which does not require normal distribution or homogenous variances. 


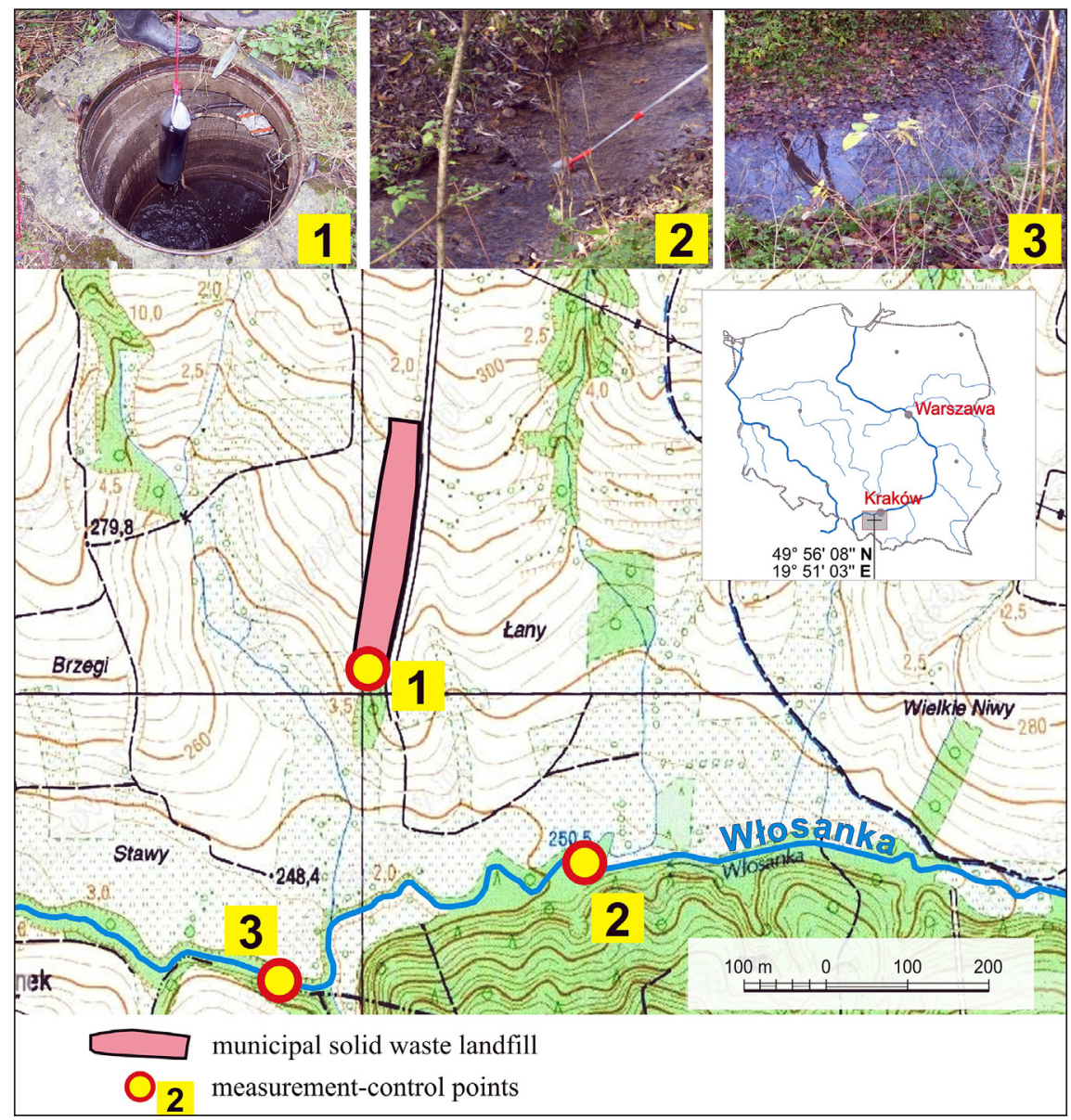

Figure 1. Location of solid waste municipal landfill site and measurement points

\section{DESCRIPTION OF THE INVESTIGATED OBJECT}

The investigated municipal landfill site and the Włosanka stream are located in Kulerzów village, Mogilany district in the south-eastern part of Kraków county. The landfill is situated in a ravine, about $40 \mathrm{~m}$ wide and 230 long. The ravine is surrounded by steep slopes between 5 and $8 \mathrm{~m}$ high crossing the hillside of Wieliczka Plateau. Geological structure of the landfill contains the Cretaceous-Tertiary and Quaternary deposits. They developed in the form of sandstones, conglomerates and shales of the Istebna layers. Cretaceous deposits are overlain by a continuous cover of Quaternary layers, mainly silt loam and residual clay. One aquifer, of $15 \mathrm{~m}$ thickness, occurs in the landfill area. It is connected with flysch deposits of the Istebna layers and composed of coarse grained sandstone. The aquifer is recharged mainly by the atmospheric precipitations, which infiltrate through the fissures and cracks. Groundwater runoff occurs towards the Włosanka stream bed according to the morphology of the terrain.
The landfill in Kulerzów was commissioned for use in 1994, as a landfill site for wastes other than dangerous or neutral. Non selected wastes were deposited. At that time not enough importance was attached to the environmental protection, so environment safe technologies were rarely applied, especially on small local landfill sites. The same happened in this case, where the landfill site did not meet the requirements for landfill base and side walls sealing with the material with permeability coefficient $\mathrm{k} \leq 1 \cdot 10^{-9} \mathrm{~m} \cdot \mathrm{s}^{-1}$ and thickness no less than $1 \mathrm{~m}$ [Rozporzadzenie MŚ 2013a]. The natural geological barrier is the loam layers at the depth of several meters below the surface level. The landfill was established to gather municipal wastes from households in the district area and to eliminate illegal dumping sites near houses in the district, as well as liquidate illegal dumps where the inhabitants abandoned their wastes. The landfill area is 1.18 ha and expected total capacity was $37493 \mathrm{~m}^{3}$. By the end of its life cycle in 2005 its filling reached about $60 \%$. Under the time of the landfill shutdown, the wastes were deposited on the ravine 
bottom in horizontal layers. They were raked up and compacted by bulldozers and then covered by a $15 \mathrm{~cm}$ thick insulating layer of soil in order to protect it against animals and effluvia of smaller pollutants. From time to time the wastes were covered by chlorinated lime. The landfill basin was shaped in the way allowing the runoff of leachate waters towards the drainage system and then to a sealed $50 \mathrm{~m}^{3}$ container. Leachates were collected from the basin bottom by a drainage pipeline made of ceramic pipes, $10 \mathrm{~cm}$ in diameter, placed in the pebble pack, covered by multi-hole reinforced concrete slabs, which function as a drainage system protection against destruction. The real amount of leachates is unknown because of missing systematic measurements. The only registered amount of disposed leachates was about $9.0 \mathrm{~m}^{3}$ per month. The other part was used for sprinkling the landfill surface using a sprinkler. Construction of this object did not involve making surrounding ditches for rainwater catching or the landfill base sealing.

Only arable fields are situated in the immediate vicinity of the landfill, there are no housing facilities. The Włosanka stream, which is the right bank tributary to the Skawinka river, flows at the distance of $300 \mathrm{~m}$ below the southern boundary of the landfill. Its catchment area is $8.65 \mathrm{~km}^{2}$. The stream, $4.71 \mathrm{~km}$ long, flows from the east to the west in a channel with $1.95 \%$ bottom slope.

\section{RESULTS}

Over the four years of the investigations, calcium concentrations ranging from 108 to 247 $\mathrm{mg} \cdot \mathrm{dm}^{-3}$ and magnesium from 52 to $126 \mathrm{mg} \cdot \mathrm{dm}^{-3}$ were registered in the water leaching from the inactive landfill. This range of values determined a low variance coefficients, respectively 26 and $20 \%$ (Table 1). Sodium concentrations in the leachates did not exceed $257 \mathrm{mg} \cdot \mathrm{dm}^{-3}$ and potassium 225 $\mathrm{mg} \cdot \mathrm{dm}^{-3}$. Their average values were on the level of $170 \mathrm{mg} \mathrm{Na} \cdot \mathrm{dm}^{-3}$ and $122 \mathrm{mg} \mathrm{K} \cdot \mathrm{dm}^{-3}$. The maximum iron concentration was $2.29 \mathrm{mg} \cdot \mathrm{dm}^{-3}$ and its average value $0.62 \mathrm{mg} \cdot \mathrm{dm}^{-3}$. Manganese concentration during the investigated period did not exceed $1.34 \mathrm{mg} \cdot \mathrm{dm}^{-3}$. The content of heavy metals, i.e. chromium, zinc, copper, cadmium, nickel and lead in leachates was low. Chromium concentration, which in people causes disorders associated with allergens and carcinogens [Ociepa-Kubicka and Ociepa 2012] ranged from 0 to $90 \mu \mathrm{g} \cdot \mathrm{dm}^{-3}$. Zinc ranged from 0 to $60 \mu \mathrm{g} \cdot \mathrm{dm}^{-3}$ and copper from 2 to $34 \mu \mathrm{g} \cdot \mathrm{dm}^{-3}$. These values are safe for the environment. Average concentrations of chromium, zinc and copper were on the levels of 35,20 and $11 \mu \mathrm{g} \cdot \mathrm{dm}^{-3}$, whereas nickel and lead content did not exceed several $\mu \mathrm{g} \cdot \mathrm{dm}^{-3}$. These values were not toxic for people or animals [Węglarzy 2007] and much lower than the values permissible by the Minister regulation [Rozporządzenie MŚ 2014b]. No cadmium con-

Table 1. Statistical parameters describing the contents of analysed metals in landfill leachate water and in the Włosanka stream water

\begin{tabular}{|c|c|c|c|c|c|c|c|c|c|c|c|}
\hline \multirow{3}{*}{\multicolumn{2}{|c|}{ Metal }} & \multirow{2}{*}{\multicolumn{4}{|c|}{ Landfill leachate water (point 1) }} & \multicolumn{6}{|c|}{ The water in the Włosanka stream } \\
\hline & & & & & & \multicolumn{3}{|c|}{ above the landfill (point 2) } & \multicolumn{3}{|c|}{ below the landfill (point 3) } \\
\hline & & $\min -\max$ & AM & median & CV [\%] & $\min -\max$ & AM & CV [\%] & $\min -\max$ & AM & $\mathrm{CV}[\%]$ \\
\hline $\mathrm{Ca}^{2+}$ & \multirow{6}{*}{$\begin{array}{l}\dot{\xi} \\
\text { हो } \\
\dot{\dot{g}} \\
\dot{\varepsilon}\end{array}$} & $108-247$ & 173 & 175 & 26 & $79-107$ & 94 & 8 & $78-103$ & 94 & 8 \\
\hline $\mathrm{Mg}^{2+}$ & & $52-126$ & 101 & 110 & 20 & $5-7$ & 6.0 & 11 & $5-7$ & 6.2 & 9 \\
\hline $\mathrm{Na}^{+}$ & & $79-257$ & 170 & 180 & 30 & $8-12$ & 10.7 & 11 & $8-13$ & 11.0 & 11 \\
\hline $\mathrm{K}^{+}$ & & $71-225$ & 122 & 116 & 31 & $1-4$ & 1.9 & 35 & $1-4$ & 2.4 & 37 \\
\hline $\mathrm{Fe}$ & & $0.07-2.29$ & 0.62 & 0.45 & 98 & $0.05-0.9$ & 0.38 & 81 & $0.01-0.81$ & 0.37 & 64 \\
\hline $\mathrm{Mn}^{2+}$ & & $0.06-1.34$ & 0.53 & 0.55 & 64 & $0.02-0.37$ & 0.10 & 96 & $0.01-0.41$ & 0.13 & 92 \\
\hline $\mathrm{Cr}$ & \multirow{6}{*}{ 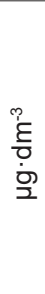 } & $0-90$ & 35 & 30 & 75 & $0-20$ & 5 & 130 & $0-10$ & 4 & 120 \\
\hline $\mathrm{Zn}$ & & $0-60$ & 20 & 20 & 74 & $0-180$ & 26 & 191 & $0-60$ & 15 & 107 \\
\hline $\mathrm{Cu}$ & & $2-34$ & 11 & 8 & 83 & $1-71$ & 11 & 183 & $0-21$ & 6 & 102 \\
\hline $\mathrm{Cd}$ & & 0 & 0 & 0 & 0 & 0 & 0 & 0 & 0 & 0 & 0 \\
\hline $\mathrm{Ni}$ & & $2-8$ & 5 & 5 & 41 & $0-4$ & 1 & 150 & $0-4$ & 1 & 150 \\
\hline $\mathrm{Pb}$ & & $0-5$ & 2 & 0 & 123 & $0-5$ & 1 & 207 & $0-4$ & 1 & 174 \\
\hline
\end{tabular}

$\mathrm{AM}$ - arithmetic mean, CV - coefficient of variation. 
tent was determined in the leachate water samples collected from the container. Analysis of the studied metals from the municipal landfill leachates (point 1), conducted in compliance with the regulation of the Minister of the Environment establishing conditions for the introduction of sewage into water bodies or soil [Rozporządzenie MŚ 2014b] revealed, that the highest permissible value was exceeded on average by $42 \mathrm{mg} \cdot \mathrm{dm}^{-3}$ only for potassium (Table 1).

Analysis of physicochemical elements supporting biological elements in the classification of the condition of surface water bodies showed that average concentrations of calcium and magnesium in the Włosanka stream water did not exceed the limit values for class 1 . However, calcium content $\left(94 \mathrm{mg} \cdot \mathrm{dm}^{-3}\right)$ in water was approximate to the limit value for class 1 [Rozporządzenie MŚ 2014a]. Regarding the substances particularly harmful to aquatic environment, the maximum content of chromium was $20 \mu \mathrm{g} \cdot \mathrm{dm}^{-3}$, copper 71 $\mu \mathrm{g} \cdot \mathrm{dm}^{-3}$ and zinc $-180 \mu \mathrm{g} \cdot \mathrm{dm}^{-3}$. In both measurement points (points 2 and 3 ) the stream waters met the requirements for purity class 1 water.

On the basis of research on priority substances, no cadmium concentrations were registered in the stream water, whereas the maximum concentration of nickel was $4 \mu \mathrm{g} \cdot \mathrm{dm}^{-3}$ and lead $5 \mu \mathrm{g} \cdot \mathrm{dm}^{-3}$ (Table 1). The above mentioned substances did not exceed the environmental quality standards, which means that water in the Włosanka stream is in good chemical condition. Water in the stream below the landfill did not worsen because the con- centrations of a majority of indices were on the equal or very similar level (Table 1).

Much higher values of the studied metals (except for copper, cadmium and zinc) were determined in the leachates from the landfill than in the stream water. The greatest, over 60 -fold differences were registered for potassium, over 15fold for magnesium and sodium, over 5-fold for manganese, chromium and nickel and 2-fold for calcium, iron and lead (Table 1).

The middle value (median) was used to compare metal concentrations in the leachates (point 1) and in the Włosanka stream water (points 2 and 3), because of the lack of normality of distribution, except for calcium. Statistical analysis revealed significantly higher concentrations of calcium, magnesium, sodium, potassium, manganese, chromium and copper in the landfill leachates (Table 2). A comparison of the metal concentrations in the Włosanka stream water above (point 2) and below (point 3) the landfill revealed non-significant statistical differences. These were $0.15 \mathrm{mg} \cdot \mathrm{dm}^{-3}$ for iron, $0.02 \mathrm{mg} \cdot \mathrm{dm}^{-3}$ for manganese and $1 \mu \mathrm{g} \cdot \mathrm{dm}^{-3}$ for copper, whereas for the other metals median values were equal (Table 3 ).

\section{CONCLUSIONS}

Over the years 2007-2010 high potassium concentrations were registered in the leachate waters for municipal landfill site. Its average concentration exceeded the admissible values stated

Table 2. Results of statistical comparison tests of metal concentration values in the landfill leachate water with the Włosanka stream water above the municipal landfill site

\begin{tabular}{|c|c|c|c|c|c|c|}
\hline \multicolumn{2}{|c|}{ Metal } & \multicolumn{2}{|c|}{ Landfill leachate water (point 1) } & \multicolumn{2}{|c|}{$\begin{array}{l}\text { The water in the stream } \\
\text { above the landfill (point 2) }\end{array}$} & \multirow{2}{*}{$\begin{array}{c}\text { Result of probability test } \\
\qquad<0.001^{*}\end{array}$} \\
\hline $\mathrm{Ca}^{2+}$ & \multirow{6}{*}{$\begin{array}{l}? \\
\stackrel{n}{E} \\
\dot{0} \\
\dot{g}\end{array}$} & $\frac{\text { Median }}{175}$ & $\begin{array}{l}\mathrm{SD} \\
46\end{array}$ & $\begin{array}{c}\text { Median } \\
95\end{array}$ & $\begin{array}{l}\mathrm{SD} \\
7.5\end{array}$ & \\
\hline $\mathrm{Mg}^{2+}$ & & 110 & 20 & 6.0 & 0.6 & $<0.001^{* *}$ \\
\hline $\mathrm{Na}^{+}$ & & 180 & 51 & 11 & 1.2 & $<0.001^{* *}$ \\
\hline $\mathrm{K}^{+}$ & & 116 & 38 & 2.0 & 0.7 & $<0.001^{* *}$ \\
\hline $\mathrm{Fe}$ & & 0.45 & 0.61 & 0.29 & 0.31 & $0.31^{* *}$ \\
\hline $\mathrm{Mn}^{2+}$ & & 0.55 & 0.34 & 0.06 & 0.10 & $<0.001^{* *}$ \\
\hline $\mathrm{Cr}$ & \multirow{5}{*}{$\begin{array}{l}\stackrel{m}{\varepsilon} \\
\dot{0} \\
\dot{0} \\
\dot{0}\end{array}$} & 30 & 27 & 0 & 7 & $<0.001^{* *}$ \\
\hline $\mathrm{Zn}$ & & 20 & 15 & 10 & 49 & $0.14^{* *}$ \\
\hline $\mathrm{Cu}$ & & 8 & 9 & 3 & 21 & $0.03^{* *}$ \\
\hline $\mathrm{Ni}$ & & 5 & 2 & 0 & 2 & $0.10^{* *}$ \\
\hline $\mathrm{Pb}$ & & 0 & 1.9 & 0 & 1.6 & $0.36^{* *}$ \\
\hline
\end{tabular}

$\mathrm{SD}$ - standard deviation, " Student's $t$-test ${ }^{* *}$ Mann-Whitney $U$-test the statistical value in red type indicates that the differences are statistically important on the level $\alpha=0.05$. 
Table 3. Results of statistical comparison tests of metal concentrations in the Włosanka stream water above and below municipal landfill site

\begin{tabular}{|c|c|c|c|c|c|c|}
\hline \multirow{2}{*}{\multicolumn{2}{|c|}{ Metal }} & \multicolumn{2}{|c|}{ Above the landfill (point 2) } & \multicolumn{2}{|c|}{ Below the landfill (point 3) } & \multirow{3}{*}{$\frac{\text { Result of probability test }}{0.98^{*}}$} \\
\hline & & Median & SD & Median & SD & \\
\hline $\mathrm{Ca}^{2+}$ & \multirow{6}{*}{ 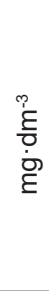 } & 95 & 7.5 & 95 & 7.4 & \\
\hline $\mathrm{Mg}^{2+}$ & & 6.0 & 0.6 & 6.0 & 0.5 & $0.46^{* *}$ \\
\hline $\mathrm{Na}^{+}$ & & 11 & 1.2 & 11 & 1.3 & $0.46^{* *}$ \\
\hline $\mathrm{K}^{+}$ & & 2.0 & 0.7 & 2.0 & 0.9 & $0.13^{* *}$ \\
\hline $\mathrm{Fe}$ & & 0.29 & 0.31 & 0.44 & 0.24 & $0.91^{* *}$ \\
\hline $\mathrm{Mn}^{2+}$ & & 0.06 & 0.10 & 0.08 & 0.12 & $0.37^{* *}$ \\
\hline $\mathrm{Cr}$ & \multirow{5}{*}{ 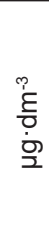 } & 0 & 7 & 0 & 5 & $0.89^{* *}$ \\
\hline $\mathrm{Zn}$ & & 10 & 49 & 10 & 16 & $0.73^{* *}$ \\
\hline $\mathrm{Cu}$ & & 3 & 21 & 4 & 7 & $0.78^{* *}$ \\
\hline $\mathrm{Ni}$ & & 0 & 2 & 0 & 2 & $1^{* *}$ \\
\hline $\mathrm{Pb}$ & & 0 & 1.6 & 0 & 1.4 & $0.98^{* *}$ \\
\hline
\end{tabular}

$\mathrm{SD}$ - standard deviation, ${ }^{*}$ Student's $t$-test ${ }^{* *}$ Mann-Whitney $U$-test.

in the regulation in force on conditions for the introduction of sewage into water bodies or soil. On the other hand, the contents of heavy metals, regarded as particularly harmful for the environment was on a low level. Obtained research results confirm that the leachates from the closed municipal landfill pose a potential source of the environment pollution.

Waters along the analysed reach of the Włosanka stream met the requirements of water purity class 1 . Metal concentrations in water did not exceed normative values and did not pose a hazard to the aquatic ecosystem. The chemical condition of the stream water was good. No significant differences between the studied metal concentrations (including heavy metals) in the point above or below the municipal landfill were stated on the basis of statistical analysis. The landfill leachates did not impact significantly a change in the analysed metals concentrations in the stream water.

Compliance with the regulations and appropriate adjustment of the installation to the requirements of the natural environment protection caused that leachates from the municipal landfill site in Kulerzów do not threaten the Włosanka stream waters. Despite the lack of proper landfill basin sealing, properly made drainage system and its container make possible collecting the leachates and their disposal at the sewage treatment plant, which reduces pollutant penetration into the environment, including the Włosanka stream waters. Because the process of pollutant leaching from the landfill site may take from several dozen to several hundred years, the landfill filling must be checked regularly to prevent its overfilling. Monitoring of the physicochemical composition of the leachate waters is necessary, at least during the period stated in the regulation of the Minister of the Environment on the scope, period, method and conditions of landfill sites monitoring.

\section{REFERENCES}

1. Bogdał A., Kowalik T., Kanownik W., Ostrowski K., Wiśnios M. 2012. Ocena stanu fizykochemicznego wód opadowych i odpływających ze zlewni potoku Wolninka. Gaz, Woda i Technika Sanitarna, 8, 362-365.

2. Czop M., Pieniążek K. 2010. Analiza jakościowa odcieków ze składowisk miejskich w czasie ich eksploatacji. Archives of Waste Management and Environmental Protection, 12(3), 19-28.

3. Długosz J. 2012. Characteristics of the composition and quantity of leachate from municipal landfills - a review. Archives of Waste Management and Environmental Protection, 149(4), 19-30.

4. Dmochowska A., Dmochowski D. 2011. Zawartość substancji nieorganicznych oraz zanieczyszczeń organicznych w odciekach ze składowiska odpadów komunalnych w Łubnej. Polski Przegląd Medycyny i Psychologii Lotniczej, 4(17), 371-380.

5. Grzyb J., Frączek K., Chmiel M.J. 2015. Zagrożenia mikrobiologiczne wód podziemnych w strefie oddziaływania składowiska odpadów komunalnych. Woda-Środowisko-Obszary Wiejskie, ITP w Falentach, 15, 1(49), 47-58.

6. Janeczko-Mazur A., Nowosielski M. 2009. Badania monitoringowe wód $\mathrm{w}$ rejonie nieczynnego 
składowiska odpadów komunalnych w Łące k. Bolesławca (woj. dolnośląskie). Gaz, Woda i Technika Sanitarna, 9, 23-25.

7. Kanownik W., Rajda W. 2011. Wpływ oczyszczonych ścieków na jakość wód w odbiorniku. Gaz, Woda i Technika Sanitarna, 10, 366-368.

8. Koc-Jurczyk J., Różak J. 2011. Skład odcieków pochodzących z rekultywowanego składowiska odpadów komunalnych. Inżynieria Ekologiczna, 27, 72-80.

9. Kowalik T., Bogdał A., Borek Ł., Kogut A. 2015. The effect of treated sewage outflow from a modernized sewage treatment plant on water quality of the Breń river. Journal of Ecological Engineering, 16(4), 96-102.

10. Kowalik T., Kanownik W., Bogdał A., Policht-Latawiec A. 2014. Wpływ zmian użytkowania zlewni wyżynnej na kształtowanie jakości wody powierzchniowej. Annual Set The Environment Protection (Rocznik Ochrona Środowiska), 16, 223-238.

11. Longe E.O., Balogun M.R. 2010. Groundwater quality assessment near a Municipal Landfill, Lagos, Nigeria. Res. J. of Appl. Sci. Eng. Technol., 2(1), 39-44.

12. Mizerna K., Bożym M. 2015. Monitoring of water quality at the municipal waste landfills. Archives of Waste Management and Environmental Protection, 17(4), 51-58.

13. Motyka J., Adamczyk Z., Czop M., D’obyrn K. 2005. Wpływ składowiska odpadów komunalnych w Ujkowie koło Olkusza na jakość wód podziemnych. Gospodarka Surowcami Mineralnymi, 21(1), 131-153.

14. Ociepa-Kubicka A., Ociepa E. 2012. Toksyczne oddziaływanie metali ciężkich na rośliny, zwierzęta i ludzi. Inżynieria i Ochrona Środowiska, 15(2), 169-180.

15. Ogundiran O.O., Afolabi T.A. 2008. Assessment of the physicochemical parameters and heavy metal toxicity of leachates from municipal solid waste open dumpsite. Int. J. Environ. Sci. Tech., 5(2), 243-250.

16. Öman C.B., Junestedt C. 2008. Chemical characterization of landfill leachates -400 parameters and compounds. Waste Management, 10, 1876-1891.

17. Piniarski W., Macias A. 2015. Assessment of the impact of municipal management on local environment in environmentally valuable areas on the ex ample of town and community of Pobiedziska. Archives of Waste Management and Environmental Protection, 17(4), 29-38.

18. PN-EN ISO 5667-1: 2008: Jakość wody - Pobieranie próbek - Część 1: Wytyczne dotyczące opracowywania programów pobierania próbek i technik pobierania.
19. PN-EN ISO 5667-3: 2013: Jakość wody - Pobieranie próbek - Część 3: Utrwalanie i postępowanie z próbkami wody.

20. PN-ISO 5667-10: 1997: Jakość wody - Pobieranie próbek - Wytyczne pobierania próbek ścieków.

21. PN-ISO 5667-6: 2003: Jakość wody - Pobieranie próbek - Część 6: Wytyczne dotyczące pobierania próbek z rzek i strumieni.

22. Policht-Latawiec A., Kanownik W. 2015. Hydrochemical conditions of the Lososina river water management in the area of Tymbark. Journal of Ecological Engineering, 16(5), 151-159.

23. Przydatek G. 2012. Ocena sprawności systemu odwodnienia eksploatacji składowiska odpadów komunalnych. Infrastruktura i Ekologia Terenów Wiejskich PAN, 2/III/, 217-226.

24. Rozporządzenie Ministra Środowiska z dnia 30 kwietnia 2013 r. w sprawie składowisk odpadów (Dz. U. 2013, poz. 523), 2013a.

25. Rozporządzenie Ministra Środowiska z dnia 21 listopada 2013 r. zmieniające rozporządzenie MŚ z dnia 15 listopada 2011 r. w sprawie form i sposobu prowadzenia monitoringu jednolitych części wód powierzchniowych i podziemnych (Dz. U. 2013, poz. 1558), 2013b.

26. Rozporządzenie Ministra Środowiska z dnia 22 października 2014 r. w sprawie sposobu klasyfikacji stanu jednolitych części wód powierzchniowych oraz środowiskowych norm jakości dla substancji priorytetowych. (Dz. U. 2014, poz. 1482), 2014a.

27. Rozporządzenie Ministra Środowiska z dnia 18 listopada 2014 roku w sprawie warunków, jakie należy spełnić przy wprowadzeniu ścieków do wód lub do ziemi, oraz w sprawie substancji szczególnie szkodliwych dla środowiska wodnego. (Dz. U. 2014, poz. 1800), 2014b.

28. Rzepa S., Siciński W., Toporowicz T., Twardowski R. 2006. Wpływ zrekultywowanego składowiska odpadów komunalnych na jakość wód podziemnych i powierzchniowych na przykładzie składowiska w Kurowicach koło Głogowa. Ochrona Środowiska, 28(3), 55-58.

29. Słomczyńska B, Słomczyński T. 2004. Physicochemical and toxicological characteristics of leachates from MSW landfills. Polish J. Environ. Stud., 13(6), 627-637.

30. Srivastava S.K., Ramanathan A.L. 2008. Geochemical assessment of groundwater quality in vicinity of Bhalswa landfill, Delhi, India, using graphical and multivariate statistical methods. Environmental Geology, 53(7), 1509-1528.

31. Szyłak-Szydłowski M. 2011. Ocena zmian toksyczności odcieków ze składowiska odpadów podczas ich biologicznego oczyszczania. Ochrona Środowiska, 33(2), 65-68. 
32. Szymańska-Pulikowska A. 2010. Ocena właściwości wód odciekowych z krajowych składowisk odpadów komunalnych. Infrastruktura i Ekologia Terenów Wiejskich PAN, 8, 141-150.

33. Vergara S.E., Tchobanoglous G. 2012. Municipal Solid Waste and the Environment: A Global Perspective. Annual Review of Environment and Resources, 37, 277-309.

34. Węglarzy K. 2007. Metale ciężkie - źródła zanieczyszczeń i wpływ na środowisko. Wiadomości Zootechniczne, XLV, 3, 31-38.
35. Wiater J. 2011. Wpływ składowisk odpadów komunalnych na jakość wód podziemnych i właściwości gleb. Inżynieria Ekologiczna, 26, 133-146.

36. Wiercik P., Szymańska-Pulikowska A. 2010. Wpływ składowiska odpadów komunalnych w Wojczycach na jakość wód podziemnych. Infrastruktura i Ekologia Terenów Wiejskich, 8(2), 151-162.

37. Williams P.T. 2002. Emissions from Solid Waste Management Activities. Issues in Environmental Science and Technology, 18, 141-170. 